\title{
Pelleted Beet Pulp Substituted for High-Moisture Corn: 1. Effects on Feed Intake, Chewing Behavior, and Milk Production of Lactating Dairy Cows
}

\author{
J. A. Voelker and M. S. Allen \\ Department of Animal Science \\ Michigan State University, \\ East Lansing 48824-1225
}

\begin{abstract}
The effects of increasing concentrations of dried, pelleted beet pulp substituted for high-moisture corn on intake, milk production, and chewing behavior were evaluated using eight ruminally and duodenally cannulated multiparous Holstein cows in a duplicated $4 \times 4$ Latin square design with 21 -d periods. Cows were 79 \pm 17 (mean $\pm \mathrm{SD}$ ) $\mathrm{d}$ in milk at the beginning of the experiment. Experimental diets with $40 \%$ forage (corn silage and alfalfa silage) and $60 \%$ concentrate contained $0,6.1,12.1$, or $24.3 \%$ beet pulp substituted for highmoisture corn on a dry matter basis. Diet concentrations of neutral detergent fiber (NDF) and starch were 24.3 and $34.6 \%$ ( $0 \%$ beet pulp), 26.2 and $30.5 \%$ (6\% beet pulp), 28.0 and $26.5 \%$ (12\% beet pulp), and 31.6 and $18.4 \%$ (24\% beet pulp), respectively. Increasing beet pulp in the diet caused a linear decrease in dry matter intake (DMI). Time spent eating per day and per kilogram of DMI increased, and sorting against NDF tended to increase, with added beet pulp. Substituting beet pulp for corn caused a quadratic response in milk fat yield, with the highest yield for the $6 \%$ beet pulp treatment. A tendency was detected for a similar quadratic response in $3.5 \%$ fat-corrected milk yield. Lower plasma insulin concentration may have resulted in lower body condition gain for cows fed diets with higher beet pulp concentration. Partial substitution of pelleted beet pulp for high-moisture corn decreased intake but also may have permitted greater fat-corrected milk yield.
\end{abstract}

(Key words: beet pulp, high-moisture corn, milk yield, ruminal fill)

Abbreviation key: $\mathbf{B P}=$ beet pulp, $\mathbf{0 B P}=0 \%$ beet pulp treatment, $\mathbf{6 B P}=6 \%$ beet pulp treatment, 12BP $=12 \%$ beet pulp treatment, $\mathbf{2 4 B P}=24 \%$ beet pulp treat-

Received November 12, 2002.

Accepted March 3, 2003.

Corresponding author: M. S. Allen; e-mail: allenm@pilot.msu.edu. ment, HMC = high-moisture corn, INDF = indigestible NDF, pdNDF = potentially digestible NDF.

\section{INTRODUCTION}

Grain is often substituted for forage in diets for highproducing cows in an effort to increase intake and milk yield. Reducing dietary NDF concentration by decreasing the forage-to-concentrate ratio usually increases DMI, probably by reducing the filling effect of the diet (Allen, 2000). However, increasing dietary starch can also negatively affect feed intake and milk production. Feeding less forage NDF reduces chewing (Allen, 1997), which can reduce flow of saliva and its buffers into the rumen. This could possibly reduce ruminal $\mathrm{pH}$, fiber digestion, and milk fat concentration. Propionate production can increase with greater dietary starch content and can depress DMI (Anil and Forbes, 1980), limiting milk synthesis.

Adding nonforage NDF to low-forage diets might reduce the negative effects of increased starch fermentation without increasing the filling effect of the diet to the same extent as forage NDF. The responses of DMI to various nonforage fiber sources substituted for grain are not consistent (Allen, 2000). Beet pulp contains approximately $40 \% \mathrm{NDF}$ and is unique in its high concentration of neutral-detergent soluble fiber, especially pectic substances. Previous experiments have reported a variety of responses in DMI to the substitution of dried beet pulp for corn grain. Of four experiments that substituted beet pulp for grain in a TMR, two reported increased DMI (Clark and Armentano, 1997; O'Mara et al., 1997), one reported decreased DMI (Mansfield et al., 1994), and one measured no effect of beet pulp on DMI (Swain and Armentano, 1994). Among the same experiments, three reported no effects of treatment on milk yield (Mansfield et al., 1994; Swain and Armentano, 1994; Clark and Armentano, 1997), and one reported decreased milk yield when beet pulp was substituted for corn grain (O'Mara et al., 1997). Fat-corrected milk yield, when reported, was not affected by treatment. In these experiments, beet pulp comprised at 
Table 1. Nutrient composition of high-moisture corn and dried, pelleted beet pulp.

\begin{tabular}{llr}
\hline Nutrient & $\begin{array}{l}\text { High-moisture } \\
\text { corn }\end{array}$ & $\begin{array}{r}\text { Beet } \\
\text { pulp }\end{array}$ \\
\hline DM, \% as fed & 71.5 & 84.9 \\
\cline { 2 - 3 } & 10.0 & \% of DM \\
NDF & 8.3 & 39.9 \\
CP & 3.8 & 8.9 \\
Indigestible NDF & 70.5 & 8.0 \\
Starch & 4.7 & 3.9 \\
Ether extract & 1.0 & 0.7 \\
Ash & & 7.8 \\
\hline
\end{tabular}

least $15 \%$ of diet DM. However, the effects of rate of substitution and the mechanisms of intake regulation for diets containing beet pulp have not previously been investigated.

Substituting beet pulp for high-moisture corn in a diet with a low forage content should maximize DMI and $3.5 \% \mathrm{FCM}$ yield at one or more rates of inclusion. Therefore, this experiment investigated the responses to four concentrations of beet pulp substituted for highmoisture corn $(0,6,12$, and $24 \%$ of diet DM) for feed intake, meal patterns, chewing behavior, ruminal nutrient pools, and milk yield and composition.

\section{MATERIALS AND METHODS}

This paper is the first of three papers in a series from one experiment that evaluated effects of the substitution of dried, pelleted beet pulp for high-moisture corn. This paper discusses treatment effects on feed intake and milk production, and the companion papers focus on digestion (Voelker and Allen, 2003a) and ruminal fermentation, including efficiency of microbial nitrogen production (Voelker and Allen, 2003b). Experimental procedures were approved by the All University Committee on Animal Use and Care at Michigan State University.

\section{Cows and Treatments}

Eight multiparous Holstein cows ( $79 \pm 17$ DIM; mean \pm SD) from the Michigan State University Dairy Cattle Teaching and Research Center were assigned randomly to a duplicated $4 \times 4$ Latin square balanced for carryover effects in a dose-response arrangement of treatments. Treatments were diets containing dried, pelleted beet pulp (BP) at 0, 6, 12, and 24\% substituted for highmoisture corn (HMC) on a DM basis. Treatment periods were $21 \mathrm{~d}$, with the final $10 \mathrm{~d}$ used to collect samples and data. Cows were cannulated ruminally and duodenally prior to calving and assigned randomly to treatment sequence. Surgery was performed at the Department of Large Animal Clinical Science, College of Veterinary Medicine, Michigan State University. At the beginning of the experiment, empty BW (ruminal digesta removed) of cows was $516 \pm 64 \mathrm{~kg}$ (mean $\pm \mathrm{SD}$ ).

Nutrient composition for HMC and BP are shown in Table 1. Experimental diets contained $40 \%$ forage (50:50 corn silage: alfalfa silage), HMC, BP at 0 (0BP), $6(\mathbf{6 B P}), 12(\mathbf{1 2 B P})$, and $24 \%($ 24BP) of diet DM, a premixed protein supplement (soybean meal, corn distiller's grains, and blood meal), and a mineral and vitamin mix (Table 2). All diets were formulated for $18 \%$ dietary $\mathrm{CP}$ and fed as TMR.

\section{Data and Sample Collection}

Throughout the experiment, cows were housed in tie stalls and fed once daily $(1100 \mathrm{~h})$ at $110 \%$ of expected intake. Amounts of feed offered and orts were weighed for each cow daily. Samples of all diet ingredients (0.5 $\mathrm{kg})$ and orts from each cow (12.5\%) were collected daily on d 12 to 19 and combined into one sample per period. Cows were milked twice daily in their stalls during the feeding behavior monitoring phase (d 16 to 19) and in a milking parlor during the rest of each period. Milk yield was measured, and milk was sampled, at each milking on d 16 to 19. Empty BW was measured after evacuation of ruminal digesta on the day immediately before the start of the first period, and on $d 21$ of each period. Body condition score was determined on the same days by three trained investigators blinded to treatments (Wildman et al., 1982; five-point scale where $1=$ thin and $5=$ fat).

Feeding behavior was monitored from d 16 to 19 (96 h) of each period by a computerized data acquisition system (Dado and Allen, 1993). Data of chewing activities, feed disappearance, and water consumption were recorded for each cow every $5 \mathrm{~s}$. When chewing equipment malfunctioned for an individual cow during a 24$\mathrm{h}$ period (1100 to $1100 \mathrm{~h}$ ), chewing behavior was deleted for that cow during that 24 -h period. The system successfully collected $83.1 \%$ of the total chewing behavior data (average $3.4 \mathrm{~d}$ per cow per period). Daily means were calculated for number of meal bouts per day, interval between meals, meal size, eating time, ruminating time, and total chewing time. These response variables were calculated as daily means, then averaged over the $4 \mathrm{~d}$ for each period.

Blood was collected from a coccygeal vessel into tubes containing sodium heparin every $9 \mathrm{~h}$ from d 12 to 14 , starting at $1400 \mathrm{~h}$ on $\mathrm{d} 12$, so that samples represented 3 -h intervals of a 24 -h period in order to account for diurnal variation. Blood was centrifuged at $2000 \times g$ for 15 min immediately after sample collection, and 
Table 2. Ingredient and nutrient composition of experimental diets.

\begin{tabular}{|c|c|c|c|c|}
\hline & $0 \% \mathrm{BP}$ & $6 \% \mathrm{BP}$ & $12 \% \mathrm{BP}$ & $24 \% \mathrm{BP}$ \\
\hline \multicolumn{5}{|l|}{ Ingredients } \\
\hline Corn silage $^{1}$ & 20.1 & 20.1 & 20.1 & 20.1 \\
\hline Alfalfa silage $^{2}$ & 19.9 & 19.9 & 19.9 & 19.9 \\
\hline Protein $\operatorname{mix}^{3}$ & 19.5 & 19.5 & 19.5 & 19.5 \\
\hline Mineral vitamin $\operatorname{mix}^{4}$ & 4.8 & 4.8 & 4.8 & 4.8 \\
\hline Dried, pelleted beet pulp & 0 & 6.1 & 12.1 & 24.3 \\
\hline High-moisture corn & 35.6 & 29.5 & 23.5 & 11.4 \\
\hline \multicolumn{5}{|l|}{ Nutrient } \\
\hline DM & 50.2 & 50.5 & 50.8 & 51.6 \\
\hline Starch & 34.6 & 30.5 & 26.5 & 18.4 \\
\hline $\mathrm{NDF}$ & 24.3 & 26.2 & 28.0 & 31.6 \\
\hline Indigestible NDF & 9.4 & 9.6 & 9.8 & 10.2 \\
\hline Forage NDF & 17.1 & 17.1 & 17.1 & 17.1 \\
\hline $\mathrm{CP}$ & 18.0 & 18.0 & 18.0 & 18.1 \\
\hline Rumen-undegraded $\mathrm{CP}^{5}$ & 11.6 & 11.4 & 11.3 & 10.9 \\
\hline$\%$ Starch from high-moisture corn & 72.7 & 68.3 & 62.6 & 43.7 \\
\hline$\%$ NDF from forage & 70.2 & 65.3 & 61.1 & 54.1 \\
\hline$\%$ NDF from beet pulp & 0.0 & 9.3 & 17.3 & 30.7 \\
\hline
\end{tabular}

${ }^{1}$ Corn silage contained $36.2 \% \mathrm{DM}$ (as fed) and (DM basis) $43.5 \% \mathrm{NDF}, 7.6 \% \mathrm{CP}, 13.4 \%$ indigestible NDF, $28.5 \%$ starch, and $3.8 \%$ ash.

${ }^{2}$ Alfalfa silage contained $34.6 \% \mathrm{DM}$ (as fed) and (DM basis) $41.8 \% \mathrm{NDF}, 19.5 \% \mathrm{CP}, 26.1 \%$ indigestible NDF, $3.0 \%$ starch, and $8.1 \%$ ash.

${ }^{3}$ Protein mix contained $75 \%$ soybean meal, $20 \%$ corn distillers grains (with solubles), and 5\% blood meal.

${ }^{4}$ Mineral vitamin mix contained $10.4 \%$ trace mineral premix, $0.4 \%$ vitamin $\mathrm{D}, 0.4 \%$ vitamin $\mathrm{A}, 2.7 \%$ magnesium oxide, $22.3 \%$ dicalcium phosphate, and $63.8 \%$ dry ground corn as a carrier.

${ }^{5}$ Rumen-degraded protein estimated using values from NRC (2001).

plasma was harvested and frozen at $-20^{\circ} \mathrm{C}$ until analysis.

Ruminal contents were evacuated manually through the ruminal cannula at $1500 \mathrm{~h}$ ( $4 \mathrm{~h}$ after feeding) on $\mathrm{d}$

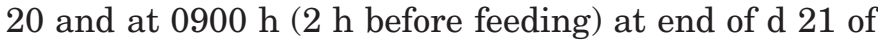
each period. Total ruminal content mass and volume were determined. During evacuation, $10 \%$ aliquots of digesta were separated to allow accurate sampling. Aliquots were squeezed through a nylon screen (1-mm pore size) to separate into primarily solid and liquid phases. Samples were taken from both phases to determine nutrient pool size, and additional liquid samples were taken to measure VFA concentration and rumen fluid consistency. All samples except the consistency sample were frozen immediately at $-20^{\circ} \mathrm{C}$.

\section{Sample and Statistical Analysis}

Diet ingredients and orts were dried in a $55^{\circ} \mathrm{C}$ forcedair oven for $72 \mathrm{~h}$ and analyzed for DM concentration. All samples were ground with a Wiley mill (1-mm screen; Authur H. Thomas, Philadelphia, PA). Rumen liquid and solid subsamples were lyophilized (Tri-Philizer MP, FTS Systems, Stone Ridge, NY), ground, and recombined according to the original ratio of solid and liquid DM. Samples were analyzed for ash, NDF, indigestible NDF (INDF), CP, and starch. Ash concentration was determined after $5 \mathrm{~h}$ of oxidation at $500^{\circ} \mathrm{C}$ in a muffle furnace. Concentrations of NDF were determined according to Van Soest et al. (1991, method A). Indigestible NDF was estimated as NDF residue after 120-h in vitro fermentation (Goering and Van Soest, 1970). Rumen fluid for the in vitro incubations was collected from a nonpregnant dry cow fed only alfalfa hay. Fraction of potentially digestible NDF (pdNDF) was calculated by difference (1.00 - INDF). Forage samples were analyzed for ADF and sulfuric acid lignin content (Van Soest et al., 1991). Crude protein was analyzed according to Hach et al. (1987). Starch was measured by an enzymatic method (Karkalas, 1985) after samples were gelatinized with sodium hydroxide. Glucose concentration was measured using a glucose oxidase method (Glucose kit \#510; Sigma Chemical Co., St. Louis, MO), and absorbance was determined with a micro-plate reader (SpectraMax 190, Molecular Devices Corp., Sunnyvale, CA). Concentrations of all nutrients except DM were expressed as percentages of DM determined by drying at $105^{\circ} \mathrm{C}$ in a forced-air oven for more than $8 \mathrm{~h}$.

A commercial kit was used to determine plasma concentration of insulin (Coat-A-Count, Diagnostic Products Corporation, Los Angeles, CA), glucose (Glucose kit \#510; Sigma Chemical Co.), NEFA (NEFA C-kit; Wako Chemicals USA, Richmond, VA), and $\beta$-hydroxybutyrate (BHBA; kit \#310-A; Sigma Chemical Co.). Milk samples were analyzed for fat, true protein, and 
lactose with infrared spectroscopy by Michigan DHIA (East Lansing).

Energy values were calculated as follows:

$\mathrm{NE}_{\mathrm{L}}$ intake $=\mathrm{DMI}(\mathrm{kg}) \times(0.0245 \times \mathrm{TDN}(\%))(\mathrm{NRC}$, 1989) [OM digestibility for calculation of TDN was measured as reported in Voelker and Allen (2003a)];

Milk NE $(\mathrm{Mcal} / \mathrm{kg})=0.0929 \times($ Fat \% $)+0.0563 \times($ True Protein\% $)+0.0395 \times($ Lactose\% $)($ NRC, 2001$)$;

Milk NE $($ Mcal/d $)=\mathrm{MY}(\mathrm{kg}) \times[0.0929 \times($ Fat \% $)$

$+0.0563 \times($ True Protein $\%)+0.0395$

$\times($ Lactose\% $)](\mathrm{NRC}, 2001)$;

$$
\mathrm{NE}_{\mathrm{M}}=0.080 \times \mathrm{BW}^{0.75}(\mathrm{NRC}, 2001) ;
$$

and $\mathrm{NE}_{\mathrm{L}}$ balance $=\mathrm{NE}_{\mathrm{L}}$ intake $-\mathrm{NE}_{\mathrm{M}}-\mathrm{NE}_{\mathrm{L}}(\mathrm{Mcal} / \mathrm{d})$.

Ruminal pool sizes (kg) of OM, NDF, INDF, and starch were determined by multiplying the concentration of each component in DM by the ruminal digesta DM weight $(\mathrm{kg})$.

Hunger and satiety ratios were calculated as follows (Forbes, 1995):

Hunger ratio $=$ meal $\mathrm{kg} \mathrm{DM} /$ premeal interval; and

Satiety ratio $=$ meal $\mathrm{kg} \mathrm{DM} /$ postmeal interval.

Ratios were calculated for individual meals and averaged for the $4 \mathrm{~d}$ of feeding behavior data collection.

All data were analyzed using the fit model procedure of JMP (Version 4, SAS Institute, Cary, NC) according to the following model:

$$
\mathrm{Y}_{\mathrm{ijk}}=\mu+\mathrm{C}_{\mathrm{i}}+\mathrm{P}_{\mathrm{j}}+\mathrm{T}_{\mathrm{k}}+\mathrm{e}_{\mathrm{ijk}},
$$

where

$$
\begin{aligned}
\mu & =\text { overall mean } \\
\mathrm{C}_{\mathrm{i}} & =\text { random effect of cow }(\mathrm{i}=1 \text { to } 8), \\
\mathrm{P}_{\mathrm{j}} & =\text { fixed effect of period }(\mathrm{j}=1 \text { to } 4) \\
\mathrm{T}_{\mathrm{k}} & =\text { fixed effect of treatment }(\mathrm{k}=1 \text { to } 4), \\
\mathrm{e}_{\mathrm{ijk}} & =\text { residual, assumed to be normally distributed. }
\end{aligned}
$$

Period $\times$ treatment interaction was originally evaluated, but it was removed from the statistical model because it was not significant for response variables of primary interest. Linear and quadratic dose-response effects were evaluated using the same model with diet percent $\mathrm{BP}(0,6,12$, and $24 \%)$ in place of the fixed effect of treatment. Pearson correlation coefficients were determined between cow-period observations for some parameters. Treatment effects, linear and quadratic responses, and correlations were declared significant at $P<0.05$, and tendencies were declared at $P<0.10$.

Data from two cow-periods were excluded from statistical analysis. One cow developed a cecal torsion requiring surgery early in period 3 ; data and samples were not collected from this cow during period 3, but she recovered sufficiently for her period 4 data to be used. Period 4 data from a second cow were excluded after she showed signs of estrus during the collection period because her feed intake and milk yield were outliers (outside the 95\% confidence interval for cow-period observations).

\section{RESULTS AND DISCUSSION}

\section{Feed Intake}

As beet pulp was increasingly substituted for highmoisture corn, DMI decreased $(P<0.05$; Table 3$)$. Although the relationship detected was linear, DMI was similar for 0BP, $6 \mathrm{BP}$, and $12 \mathrm{BP}$, and DMI was numerically lower by approximately $2 \mathrm{~kg} / \mathrm{d}$ for $24 \mathrm{BP}$. Others have reported varied responses in DMI to substitution of BP for corn grain. Swain and Armentano (1994) reported no DMI effect. Substituting BP at 16\% of DM into a high-corn diet (Clark and Armentano, 1997) increased intake by only $0.4 \mathrm{~kg} / \mathrm{d}$, while replacing half of the corn with BP in a higher-forage diet (Mansfield et al., 1994) reduced intake by $1.3 \mathrm{~kg} / \mathrm{d}$. The diets fed in the latter experiment are the most similar to diets in the present study and had a DMI response similar to the numerical difference between 24BP and the other three treatments.

\section{Regulation of Feed Intake}

Intake can be affected by innumerable variables, such as ruminal fill, meal patterns, metabolic fuels, and ruminal patterns of fermentation and $\mathrm{pH}$. Substituting a high-fiber byproduct for grain may have resulted in the limitation of intake by physical filling effects of the diet, but "fill" is likely a composite of several physical and chemical characteristics of the diet that affect volume and mass of digesta over time (Forbes, 1995). Because volume and mass of wet ruminal contents did not decrease when DMI decreased with increasing dietary BP (Table 3), stimulation of stretch receptors in the rumen wall probably was a predominant factor signaling satiety and reducing DMI with added BP. Water content of ruminal digesta increased linearly as $\mathrm{BP}$ was substituted for HMC $(P=0.01)$, probably because BP has a higher water-holding capacity than grains and other 
Table 3. Effects of substitution of pelleted beet pulp for high-moisture corn on nutrient intake and ruminal pool.

\begin{tabular}{|c|c|c|c|c|c|c|c|c|}
\hline & \multicolumn{5}{|c|}{ Treatment LS means $^{1}$} & \multicolumn{3}{|c|}{$P^{2}$} \\
\hline & $0 \% \mathrm{BP}$ & $6 \% \mathrm{BP}$ & $12 \% \mathrm{BP}$ & $24 \% \mathrm{BP}$ & $\mathrm{SE}$ & Trt & $\mathrm{L}$ & Q \\
\hline \multicolumn{9}{|l|}{ Intake, $\mathrm{kg} / \mathrm{d}$} \\
\hline DM & 24.8 & 25.0 & 25.1 & 22.9 & 0.8 & 0.11 & $<0.05$ & 0.13 \\
\hline OM & 22.3 & 22.4 & 22.4 & 20.2 & 0.7 & 0.06 & 0.50 & 0.15 \\
\hline $\mathrm{NDF}$ & 5.7 & 6.2 & 6.6 & 6.9 & 0.2 & $<0.01$ & 0.01 & 0.15 \\
\hline Starch & 8.2 & 7.3 & 6.4 & 4.0 & 0.2 & $<0.01$ & $<0.01$ & 0.21 \\
\hline Ruminal wet contents, $\mathrm{kg}$ & 77.7 & 76.7 & 78.9 & 80.7 & 2.2 & 0.36 & 0.11 & 0.58 \\
\hline Ruminal contents volume, L & 96.1 & 92.8 & 95.5 & 96.0 & 3.0 & 0.64 & 0.49 & 0.43 \\
\hline $\begin{array}{l}\text { Ruminal contents, \% DM } \\
\text { Ruminal pool, kg }\end{array}$ & 14.2 & 13.9 & 13.4 & 13.2 & 0.4 & 0.12 & 0.01 & 0.57 \\
\hline $\begin{array}{l}\text { Ruminal pool, kg } \\
\text { DM }\end{array}$ & 11.0 & 10.4 & 10.6 & 9.9 & 0.5 & 0.19 & 0,04 & 0.74 \\
\hline $\mathrm{OM}$ & 10.1 & 9.5 & 9.7 & 9.0 & 0.5 & 0.14 & 0.03 & 0.85 \\
\hline NDF & 5.5 & 5.0 & 5.2 & 4.9 & 0.3 & 0.19 & 0.11 & 0.62 \\
\hline Potentially digestible NDF & 2.4 & 2.1 & 2.3 & 2.1 & 0.2 & 0.30 & 0.17 & 0.61 \\
\hline Indigestible NDF & 3.1 & 2.9 & 2.8 & 2.8 & 0.2 & 0.42 & 0.13 & 0.21 \\
\hline Starch & 1.24 & 1.03 & 0.87 & 0.63 & 0.08 & $<0.01$ & $<0.01$ & 0.36 \\
\hline
\end{tabular}

${ }^{1}$ Treatments were beet pulp (BP) substituted for high-moisture corn as $0,6,12$, and $24 \%$ of diet DM.

${ }^{2}$ Trt: treatment effect, L: linear effect, Q: quadratic effect.

byproducts, and similar to alfalfa and grass (Ramanzin et al., 1994; Bailoni et al., 1998). The substitution of BP for HMC probably increased the water-holding capacity of the digesta and contributed to the tendency for an apparent increase in digesta wet weight $(P=$ 0.11). Neither ruminal DM pool nor ruminal NDF pool was limiting to intake, because DM pool decreased linearly $(P=0.04)$, and NDF pool appeared to decrease linearly $(P=0.11)$, as added BP reduced DMI. Therefore, ruminal digesta volume, weight, and water-hold- ing capacity contributed to the limitation of intake by distension when HMC was replaced with BP.

Feed intake can be increased by reducing intermeal interval or by increasing meal size. Intermeal interval was not affected by treatment, nor was the amount of DM consumed per meal (Table 4). However, the response of hunger ratio (meal size/premeal interval) to BP substitution was quadratic $(P<0.01)$ and was greatest for $12 \mathrm{BP}$ and lowest for $24 \mathrm{BP}$, suggesting that hunger had the greatest effect on intake for 12BP and the

Table 4. Effects of substitution of pelleted beet pulp for high-moisture corn on meal patterns and water consumption.

\begin{tabular}{|c|c|c|c|c|c|c|c|c|}
\hline & \multicolumn{5}{|c|}{ Treatment LS means $^{1}$} & \multicolumn{3}{|c|}{$P^{2}$} \\
\hline Meals/d & 9.7 & 9.5 & 9.3 & 9.0 & 0.4 & 0.55 & 0.13 & 0.93 \\
\hline DM & 2.6 & 2.5 & 2.5 & 2.6 & 0.1 & 0.70 & 0.44 & 0.35 \\
\hline NDF & 0.61 & 0.61 & 0.68 & 0.79 & 0.04 & $<0.01$ & $<0.01$ & 0.38 \\
\hline INDF & 0.26 & 0.26 & 0.27 & 0.29 & 0.02 & 0.22 & 0.06 & 0.38 \\
\hline Eating chew rate, chews/min & 73.4 & 73.5 & 74.6 & 74.7 & 2.8 & 0.65 & 0.63 & 0.86 \\
\hline Hunger $\mathrm{ratio}^{3}, \mathrm{~kg} / \mathrm{min}$ & 0.16 & 0.19 & 0.20 & 0.14 & 0.02 & 0.03 & 0.01 & $<0.01$ \\
\hline Satiety ratio $^{3}, \mathrm{~kg} / \mathrm{min}$ & 0.27 & 0.21 & 0.25 & 0.23 & 0.04 & 0.17 & 0.22 & 0.30 \\
\hline Rumination bouts/d & 12.6 & 12.6 & 12.6 & 12.6 & 0.5 & 1.00 & 1.00 & 0.97 \\
\hline Ruminating bout length, min & 36.6 & 37.6 & 38.9 & 38.6 & 2.4 & 0.66 & 0.33 & 0.48 \\
\hline Interval between ruminating bouts, min & 70.4 & 71.2 & 67.6 & 67.5 & 2.7 & 0.45 & 0.18 & 0.95 \\
\hline Ruminating chew rate, chews/min & 60.9 & 62.3 & 62.7 & 60.9 & 1.9 & 0.39 & 0.11 & 0.09 \\
\hline
\end{tabular}

${ }^{1}$ Treatments were beet pulp (BP) substituted for high-moisture corn as $0,6,12$, and $24 \%$ of diet DM.

${ }^{2}$ Trt: treatment effect, L: linear effect, Q: quadratic effect.

${ }^{3}$ Hunger ratio $=$ meal kg DM/premeal interval; Satiety ratio = meal kg DM/postmeal interval (Forbes, 1995). 
Table 5. Effects of substitution of pelleted beet pulp for high-moisture corn on chewing time.

\begin{tabular}{|c|c|c|c|c|c|c|c|c|}
\hline & \multicolumn{5}{|c|}{ Treatment LS means $^{1}$} & \multicolumn{3}{|c|}{$P^{2}$} \\
\hline & $0 \% \mathrm{BP}$ & $6 \% \mathrm{BP}$ & $12 \% \mathrm{BP}$ & $24 \% \mathrm{BP}$ & SE & Trt & $\mathrm{L}$ & Q \\
\hline \multicolumn{9}{|l|}{ Eating time, min } \\
\hline per d & 298 & 297 & 302 & 318 & 13 & 0.21 & 0.04 & 0.44 \\
\hline per bout & 34.0 & 33.0 & 33.7 & 36.6 & 2.7 & 0.65 & 0.65 & 0.45 \\
\hline per kg of DMI & 12.0 & 11.9 & 12.2 & 13.4 & 0.5 & 0.03 & $<0.01$ & 0.17 \\
\hline per $\mathrm{kg}$ of NDF intake & 52.1 & 49.6 & 47.1 & 46.4 & 2.4 & 0.04 & $<0.01$ & 0.27 \\
\hline per $\mathrm{kg}$ of forage NDF intake & 74.1 & 73.2 & 74.7 & 83.1 & 3.0 & 0.02 & $<0.01$ & 0.11 \\
\hline Feed NDF\% - orts NDF \% & 1.0 & 1.6 & 3.8 & 2.2 & 2.0 & 0.15 & 0.07 & 0.12 \\
\hline \multicolumn{9}{|l|}{ Ruminating time, min } \\
\hline per d & 472 & 467 & 483 & 499 & 24 & 0.61 & 0.15 & 0.73 \\
\hline per bout & 35.9 & 37.1 & 38.4 & 38.1 & 2.5 & 0.65 & 0.31 & 0.45 \\
\hline per kg of DMI & 19.6 & 18.6 & 19.4 & 21.3 & 0.9 & 0.07 & 0.09 & 0.05 \\
\hline per kg of NDF intake & 82.7 & 75.8 & 73.6 & 74.6 & 4.6 & 0.18 & 0.05 & 0.12 \\
\hline per kg of forage NDF intake & 123 & 115 & 119 & 132 & 6 & 0.04 & 0.07 & 0.02 \\
\hline per kg ruminal DM pool & 44.4 & 46.0 & 46.8 & 51.3 & 3.4 & 0.31 & 0.05 & 0.78 \\
\hline per kg ruminal NDF pool & 89.2 & 98.0 & 93.3 & 104 & 8 & 0.28 & 0.13 & 0.94 \\
\hline \multicolumn{9}{|l|}{ Total chewing time, min } \\
\hline per d & 784 & 792 & 805 & 833 & 25 & 0.50 & 0.12 & 0.89 \\
\hline per bout & 35.1 & 35.3 & 36.0 & 38.0 & 1.8 & 0.64 & 0.06 & 0.77 \\
\hline per kg of DMI & 31.1 & 31.1 & 32.7 & 35.5 & 1.4 & 0.07 & 0.01 & 0.44 \\
\hline per $\mathrm{kg}$ of NDF intake & 135 & 125 & 123 & 124 & 6 & 0.22 & 0.07 & 0.15 \\
\hline per $\mathrm{kg}$ of forage NDF intake & 192 & 190 & 199 & 220 & 8 & 0.07 & 0.01 & 0.22 \\
\hline per kg ruminal DM pool & 73.5 & 74.5 & 77.6 & 83.0 & 4.7 & 0.30 & 0.04 & 0.78 \\
\hline per kg ruminal NDF pool & 148 & 159 & 154 & 168 & 11 & 0.36 & 0.12 & 0.87 \\
\hline
\end{tabular}

${ }^{1}$ Treatments were beet pulp (BP) substituted for high-moisture corn as $0,6,12$, and $24 \%$ of diet DM.

${ }^{2}$ Trt: treatment effect, L: linear effect, Q: quadratic effect.

least effect for 24BP. This quadratic response suggests that hunger eventually was counteracted by other factors limiting intake; cows might eat to minimize total discomfort resulting from both hunger and satiety signals (Forbes, 2000). Satiety ratio was unaffected by treatment $(P>0.15)$, but since hunger and satiety signals are integrated to regulate feed intake (Forbes, 1995), response of hunger ratio or satiety ratio alone cannot describe the mechanisms of intake regulation.

Across cow-period observations, DMI was not related to the number of meals per day, meal length, intermeal interval, or NDF consumed per meal (Table 6). As meal

Table 6. Pearson correlation coefficients between DMI and eating or chewing behavior.

\begin{tabular}{lc}
\hline & DMI, kg/d \\
\hline Meals/d & 0.10 \\
Meal length, min & 0.10 \\
Intermeal interval, min & -0.34 \\
Meal DM, kg/meal & $0.39^{1}$ \\
Meal NDF, kg/meal & -0.02 \\
Hunger ratio ${ }^{2}, \mathrm{~kg} / \mathrm{min}$ & $0.86^{1}$ \\
Time eating, min/d & 0.21 \\
Time eating/kg DMI & -0.34 \\
Time eating/kg forage NDF intake & $-0.38^{1}$ \\
Total chewing time (TCT), min/d & -0.01 \\
TCT/kg DMI & $-0.60^{1}$ \\
TCT/kg forage NDF intake & $-0.68^{1}$ \\
\hline${ }^{1}$ Correlation is significant $(P<0.05)$. & \\
${ }^{2}$ Calculated for each meal: kg DMI/premeal interval (Forbes, 1995$)$.
\end{tabular}

size increased, DMI also increased (Figure 1a; $R=0.39$, $P=0.04$ ), although the correlation coefficient is not high. Hunger ratio was also positively correlated with DMI (Table 6), so the ability to consume a larger amount of feed at one meal, before satiety signals such as absorption of metabolic fuels or ruminal fill overcame hunger, increased the amount of feed consumed in the entire day. Average consumption of NDF per meal increased $(P<0.001)$ with added BP (Table 4), so increasing NDF consumption per meal may have slowed feed intake. However, as will be discussed further, eating rate and time probably did not actually limit daily DMI. Whereas dried, pelleted BP might be expected to physically affect eating behavior, eating chew rate was unaffected by treatment (Table 4).

Eating time per day and per kilogram of DMI increased linearly with added BP $(P=0.04, P<0.01$, respectively), so rate of feed intake was slowed (Table 5). Others have reported no effect of BP substitution for corn on time eating per day or per kilogram of DMI (Clark and Armentano, 1997). Across cow-period observations, greater time spent in total chewing per kilogram of DMI was associated with decreased DMI (Table 6 ). As diet NDF intake increased with added BP in the present experiment, time eating per kilogram of NDF decreased $(P<0.01)$. Because forage content was equal across treatments, physical or chemical effects of BP apparently had a negative effect on rate of feed intake. 
(a)

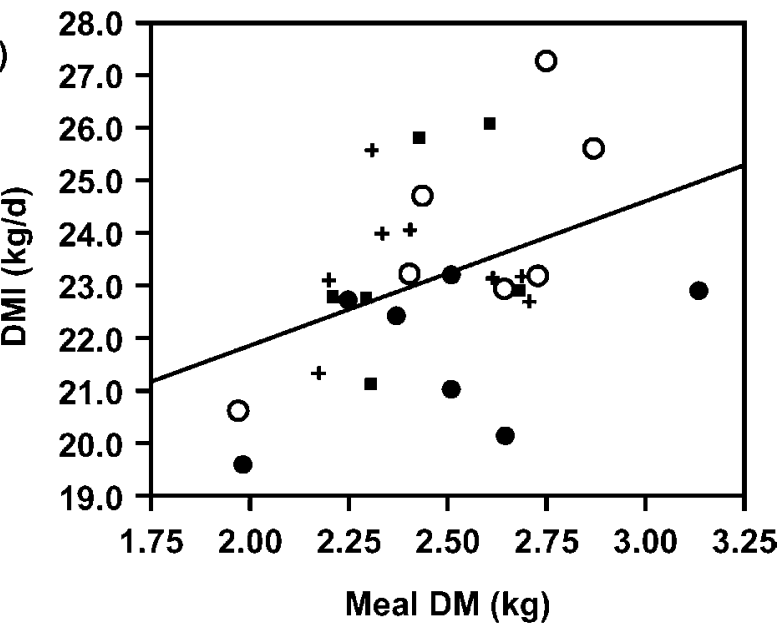

(b)

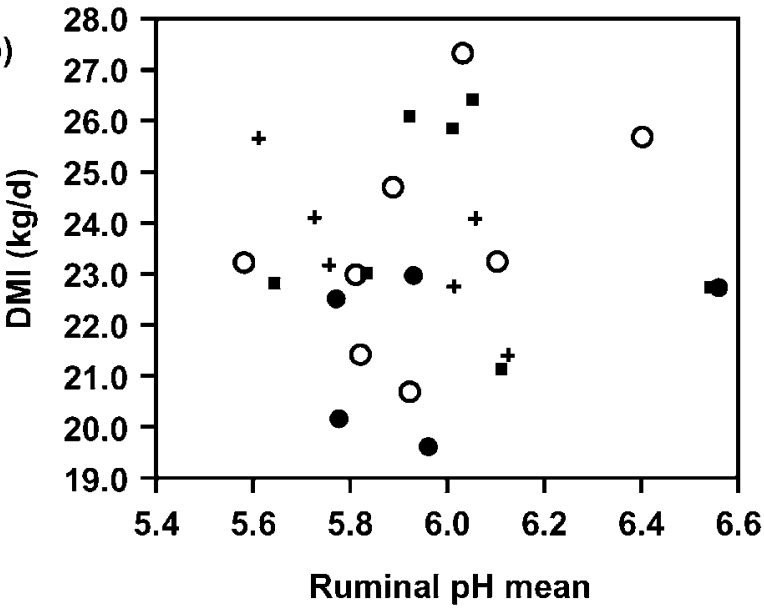

(c)

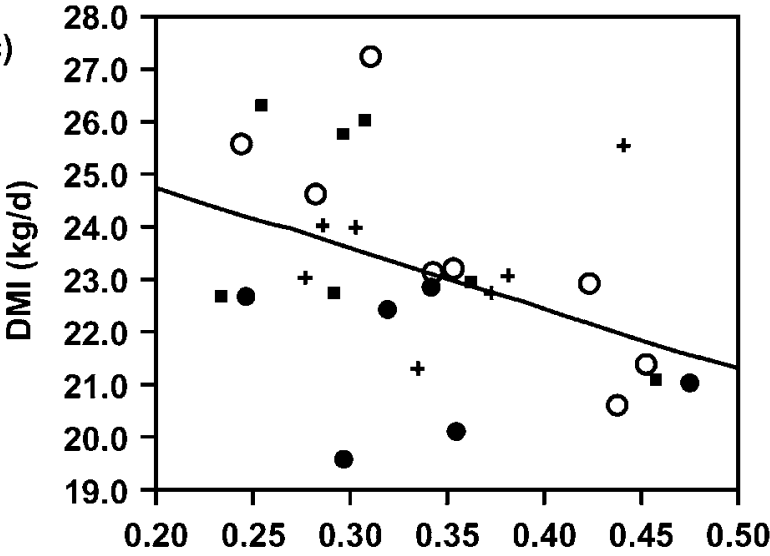

Ruminal pH standard deviation

Figure 1. Relationship between DMI ( $\mathrm{kg} / \mathrm{d})$ and (a) average $\mathrm{kg}$ $\mathrm{DMI} /$ meal $(\mathrm{DMI}=16.3+2.8 \times$ meal DMI; $\mathrm{R}=0.40 ; \mathrm{P}<0.04) ;(\mathrm{b})$ mean ruminal $\mathrm{pH}(\mathrm{R}=0.05 ; P>0.70)$; and (c) $\mathrm{pH}$ standard deviation $(\mathrm{DMI}=27.1-11.5 \times \mathrm{pH}$ standard deviation; $\mathrm{R}=-0.41 ; P<0.03) . \bigcirc$ denotes $0 \%$ beet pulp, + denotes $6 \%$ beet pulp, $\square$ denotes $12 \%$ beet pulp, and denotes $24 \%$ beet pulp (\% diet DM) substituted for highmoisture corn.
Table 7. Pearson correlation coefficients between DMI and characteristics of ruminal fermentation and $\mathrm{pH}$.

\begin{tabular}{lc}
\hline & DMI, $\mathrm{kg} / \mathrm{d}$ \\
\hline Total ruminal (VFA), $\mathrm{m} M$ & -0.23 \\
\% propionate, mol/100 mol VFA & -0.23 \\
Acetate:propionate & 0.19 \\
Valerate absorption rate, \%/h & 0.33 \\
Ruminal pH mean & 0.07 \\
Ruminal pH standard deviation & $-0.42^{1}$ \\
Ruminal pH minimum & 0.29 \\
Ruminal pH range & -0.30 \\
Ruminal pH variance & $-0.42^{1}$ \\
\hline
\end{tabular}

${ }^{1}$ Correlation is significant $(P<0.05)$.

Due to the physical form of pelleted BP, it is easily sorted. While sorting against BP was not measured, cows tended to increasingly sort against dietary NDF $(P=0.07)$ as the concentration of $\mathrm{BP}$ increased in the $\operatorname{diet}$ (Table 5). Therefore, sorting against NDF may have slowed intake. Although replacing HMC with BP tended to increase sorting and slowed rate of feed intake, time spent eating and in total chewing did not limit DMI. If eating time or total chewing time were limiting to DMI, then those responses should demonstrate a quadratic increase, increasing at a decreasing rate, as DMI was reduced with increasing dietary $\mathrm{BP}$ concentration, eventually reaching a plateau. Although linear responses were detected (Table 5), no quadratic responses were detected for time spent eating, ruminating, or in total chewing. Nor was time spent eating or in total chewing related to DMI across cow-period observations (Table 6). Therefore, eating and chewing time were not primary factors limiting feed intake.

Intake might be regulated by the metabolism of propionate in the liver (Allen, 2000), and ruminal propionate production is usually increased by greater starch fermentation. The amount of starch truly digested in the rumen decreased from 3.8 to $0.7 \mathrm{~kg} / \mathrm{d}$ (Voelker and Allen, 2003a), and ruminal molar percent of propionate in total VFA decreased quadratically (Voelker and Allen, 2003b) as starch intake was reduced by approximately half (Table 3) and as true ruminal starch digestibility decreased from $46.5 \%$ to only $16.9 \%$ (Voelker and Allen, 2003a) with added BP. Therefore, it is not likely that propionate metabolism in the liver caused the reduction in DMI with added BP, because hepatic propionate oxidation probably decreased with added BP. In addition, across cow-period observations, DMI was not related to total VFA concentration, molar percent of propionate in total VFA, or acetate:propionate (Table 7). Therefore, ruminal VFA concentration and absorption rate did not negatively affect intake.

Ruminal $\mathrm{pH}$ might be implicated in the control of feed intake, particularly in satiety because VFA are 
Table 8. Effects of substitution of pelleted beet pulp for high-moisture corn on milk production.

\begin{tabular}{|c|c|c|c|c|c|c|c|c|}
\hline & \multicolumn{5}{|c|}{ Treatment LS means $^{1}$} & \multicolumn{3}{|c|}{$P^{2}$} \\
\hline & $0 \% \mathrm{BP}$ & $6 \% \mathrm{BP}$ & $12 \% \mathrm{BP}$ & $24 \% \mathrm{BP}$ & $\mathrm{SE}$ & Trt & $\mathrm{L}$ & Q \\
\hline \multicolumn{9}{|l|}{ Yield, kg/d } \\
\hline Milk & 36.4 & 36.6 & 35.9 & 35.4 & 1.2 & 0.58 & 0.95 & 0.74 \\
\hline $3.5 \% \mathrm{FCM}^{3}$ & 37.4 & 38.4 & 38.0 & 36.8 & 1.2 & 0.20 & 0.14 & 0.07 \\
\hline Milk fat & 1.34 & 1.40 & 1.39 & 1.33 & 0.07 & 0.14 & 0.04 & 0.03 \\
\hline Milk protein & 1.13 & 1.15 & 1.15 & 1.09 & 0.03 & 0.18 & 0.29 & 0.11 \\
\hline Milk lactose & 1.80 & 1.82 & 1.78 & 1.75 & 0.07 & 0.57 & 0.99 & 0.71 \\
\hline \multicolumn{9}{|l|}{ Milk composition, \% } \\
\hline Fat & 3.72 & 3.84 & 3.90 & 3.81 & 0.22 & 0.46 & 0.12 & 0.16 \\
\hline Protein & 3.21 & 3.21 & 3.22 & 3.10 & 0.11 & 0.41 & 0.59 & 0.32 \\
\hline Lactose & 4.95 & 4.96 & 4.95 & 4.94 & 0.02 & 0.75 & 0.66 & 0.53 \\
\hline $\mathrm{kg} 3.5 \% \mathrm{FCM} / \mathrm{kg} \mathrm{DMI}$ & 1.51 & 1.54 & 1.52 & 1.62 & 0.05 & 0.26 & 0.07 & 0.49 \\
\hline
\end{tabular}

${ }^{1}$ Treatments were beet pulp (BP) substituted for high-moisture corn as $0,6,12$, and $24 \%$ of diet DM.

${ }^{2}$ Trt: treatment effect, L: linear effect, Q: quadratic effect.

${ }^{3} 3.5 \%$ fat-corrected milk.

absorbed faster in the undissociated form at lower $\mathrm{pH}$. Ruminal $\mathrm{pH}$ was measured over $96 \mathrm{~h}$ and is reported in a companion paper (Voelker and Allen, 2003b). Substituting BP for HMC decreased DMI and resulted in a range of individual mean daily $\mathrm{pH}$ values between 5.58 and 6.56 , but the decrease in DMI with added BP was not accompanied by a decrease in mean ruminal $\mathrm{pH}$ (Voelker and Allen, 2003b), and mean pH and DMI were not correlated across cow-period observations (Figure 1b). Intake was not correlated with daily range, maximum, or minimum $\mathrm{pH}$, but DMI was negatively related to daily standard deviation (Figure $1 \mathrm{c} ; \mathrm{R}=-0.41$, $P=0.03)$ and variance $(\mathrm{R}=-0.42, P=0.03)$ of ruminal $\mathrm{pH}$. The direction of cause and effect is not established by these results. Increased intake might be associated with reduced $\mathrm{pH}$ variation if cows consumed more frequent, smaller meals and thus increased intake while reducing ruminal $\mathrm{pH}$ variation. However, increased DMI was associated with greater meal size, not smaller meal size (Figure 1a), and DMI was not related to intermeal interval, so it is unlikely that the consumption of more frequent, smaller meals resulted in increased $\mathrm{DMI}$ and decreased ruminal $\mathrm{pH}$ variation. Rather, it is more likely that increased $\mathrm{pH}$ fluctuations resulted in feed intake depression. Increases in both DMI and daily $\mathrm{pH}$ range were associated with the higher starch diets (Table 3; and in Voelker and Allen, 2003b), so the negative correlation between DMI and ruminal $\mathrm{pH}$ variation is independent of the treatment effects.

Thus, feed intake was affected by both treatmentdependent and treatment-independent factors. The limitation of intake by ruminal distention was closely related to effects detected among treatment means as BP was substituted for HMC. By contrast, the relationship between $\mathrm{pH}$ variation and DMI occurred independently from treatment effects for the individual variables.

\section{Milk Production and Nutrient Partitioning}

Milk yield was not affected by $\operatorname{diet}(P>0.50$; Table 8), but increasing BP tended to have a quadratic effect $(P=0.07)$ on $3.5 \%$ FCM yield and had a quadratic effect on milk fat yield $(P=0.03)$. Yields of FCM and milk fat were highest for $6 \mathrm{BP}$ and lowest for 24BP. These effects correspond to nonsignificant quadratic patterns of raw milk yield and milk fat content in response to increasing $\mathrm{BP}$ and decreasing HMC, and they may reflect a slight response in milk lactose and fat synthesis to added $\mathrm{BP}$ at the lower concentrations. Lower FCM yield for 24BP is likely because of decreased DMI. Three of four other experiments comparing corn grain with BP in TMR reported no effect of treatment on raw milk yield (Mansfield et al., 1994; Swain and Armentano, 1994; Clark and Armentano, 1997), and those that reported FCM yield found no effect of diet (Mansfield et al., 1994; Clark and Armentano, 1997). Only one experiment (O'Mara et al., 1997) found a 1.4-kg/d decrease in raw milk yield when BP was substituted for corn in a grass-silagebased diet. Milk protein and lactose yields and concentrations were not affected in the present experiment by substituting BP for HMC (Table 8). The reduction in $\mathrm{DMI}$ with increasing $\mathrm{BP}$ was greater than the decrease in milk yield, so the efficiency of milk production $(\mathrm{kg}$ $\mathrm{FCM} / \mathrm{kg} \mathrm{DMI})$ tended to increase $(P=0.07)$ as HMC decreased and BP increased in the diet.

Beginning with a diet containing 36\% $\mathrm{HMC}$ and $35 \%$ starch, then substituting BP containing $40 \%$ NDF for the HMC not only served to test the treatment effects of two common feed ingredients; it also provided a large pool of data including variables such as intake, production, energy status, and feeding behavior, with reasonably wide ranges, under identical conditions. Relationships among these variables across cow-period observations help both to interpret treatment effects and to 
Table 9. Effects of substitution of pelleted beet pulp for high-moisture corn on energy balance, and plasma insulin, NEFA, and $\beta$-hydroxybutyrate.

\begin{tabular}{|c|c|c|c|c|c|c|c|c|}
\hline & \multicolumn{5}{|c|}{ Treatment LS Means $^{1}$} & \multicolumn{3}{|c|}{$P^{2}$} \\
\hline $\mathrm{NE}_{\mathrm{L}}$ intake $^{3}, \mathrm{Mcal} / \mathrm{d}$ & 39.8 & 39.2 & 41.0 & 37.4 & 1.2 & 0.21 & 0.38 & 0.21 \\
\hline Milk $\mathrm{NE}_{\mathrm{L}}, \% \mathrm{NE}_{\mathrm{L}}$ intake & 65.9 & 67.5 & 64.9 & 68.9 & 1.8 & 0.28 & 0.66 & 0.42 \\
\hline BW change, $\mathrm{kg} / 21 \mathrm{~d}$ & -8.0 & 6.7 & -11.6 & -1.5 & 15.8 & 0.49 & 0.50 & 0.45 \\
\hline BCS change/21 d & 0.06 & 0.11 & -0.04 & -0.05 & 0.06 & 0.15 & 0.06 & 0.93 \\
\hline $\mathrm{NE}_{\mathrm{L}}$ balance ${ }^{5}, \mathrm{Mcal} / \mathrm{d}$ & 4.0 & 2.9 & 4.9 & 2.1 & 0.9 & 0.13 & 0.54 & 0.33 \\
\hline Plasma insulin standard deviation ${ }^{6}, \mu \mathrm{IU} / \mathrm{ml}$ & 4.9 & 4.7 & 3.8 & 2.9 & 0.5 & 0.02 & $<0.01$ & 0.96 \\
\hline Plasma glucose,${ }^{7} \mathrm{mg} / \mathrm{dl}$ & 58.4 & 59.8 & 58.2 & 56.5 & 1.0 & 0.08 & 0.06 & 0.17 \\
\hline Plasma glucose:insulin, $\mathrm{mg} / \mu \mathrm{IU}$ & 4.75 & 4.73 & 5.44 & 6.48 & 0.51 & 0.02 & 0.002 & 0.46 \\
\hline Plasma NEFA,${ }^{7} \mathrm{mM}$ & 60.6 & 58.3 & 64.0 & 59.5 & 3.9 & 0.69 & 0.65 & 0.64 \\
\hline Plasma $\beta$-hydroxybutyrate, ${ }^{7}(\mathrm{mg} / \mathrm{dl})$ & 5.85 & 5.42 & 6.50 & 6.34 & 0.44 & 0.20 & 0.18 & 0.93 \\
\hline
\end{tabular}

\footnotetext{
${ }^{1}$ Treatments were beet pulp (BP) substituted for high-moisture corn as 0, 6, 12 and $24 \%$ of diet DM.

${ }^{2}$ Trt: treatment effect, L: linear effect, Q: quadratic effect.

${ }^{3} \mathrm{NE}_{\mathrm{L}(\text { intake })}=\mathrm{DMI}(\mathrm{kg}) \times(0.0245 \times \mathrm{TDN}(\%))(\mathrm{NRC}, 1989)$.

${ }^{4} \mathrm{NE}_{\mathrm{L}(\text { milk })}(\mathrm{Mcal} / \mathrm{d})=\mathrm{MY}(\mathrm{kg}) \times(0.0929 \times$ fat $\%+0.0563 \times$ true protein $\%+0.0395 \times$ lactose $\%)(\mathrm{NRC}, 2001)$

${ }^{5} \mathrm{NE}_{\mathrm{L} \text { (intake) }}-\mathrm{NE}_{\mathrm{L}(\text { maintenance) }}-\mathrm{NE}_{\mathrm{L}(\text { milk })}$, where $\mathrm{NE}_{\mathrm{L} \text { (maintenance) }}=0.080 \times \mathrm{BW}^{0.75}$ (NRC, 2001).

${ }^{6}$ Calculated using eight samples collected over $3 \mathrm{~d}$, representing 3 -h intervals of a 24 -h day.

${ }^{7}$ Measured for a composite of eight samples collected over $3 \mathrm{~d}$, representing 3-h intervals of a 24-h d.
}

clarify basic scientific principles of intake, milk production, and feeding behavior in ruminants. Among cowperiod observations, increasing ruminal $\mathrm{pH}$ (Voelker and Allen, 2003b) was associated with greater yield of FCM $(\mathrm{R}=0.43, P=0.03)$ and tended to be associated with greater fat yield, but $\mathrm{pH}$ was not related to milk fat content $(P>0.50)$.

Although intake and milk production were influenced by diet, measures of energy intake, energy partitioning to milk and output in milk, and energy balance were not affected (Table 9); nor were changes in BW different among treatments $(P>0.45)$. Whereas partitioning of absorbed energy to milk (milk $\mathrm{NE}_{\mathrm{L}}$ as a percent of $\mathrm{NE}_{\mathrm{L}}$ intake) was not affected by adding BP, a linear tendency $(P=0.06)$ was detected for a slightly more negative change in BCS; as BP replaced HMC in the diets, cows likely mobilized nutrients from body reserves for milk production, rather than adding condition as they did for $0 \mathrm{BP}$ and $6 \mathrm{BP}$.

\section{Plasma $\beta$-Hydroxybutyrate}

The concentration of BHBA in blood plasma was not different across treatments (Table 9). Plasma BHBA was not correlated with the concentration of butyrate in rumen fluid $(P>0.85)$ but was positively correlated with the ruminal pool (mol) of butyrate $(\mathrm{R}=0.46, P=$ 0.01 ) and tended to be positively correlated with the molar proportion of butyrate in total ruminal VFA ( $R$ $=0.34, P=0.07)$. Plasma BHBA concentration was also positively correlated with milk fat yield $(\mathrm{R}=0.37, P=$
0.04 ) and tended to be positively correlated with both $3.5 \%$ FCM yield $(\mathrm{R}=0.34, P=0.07)$ and milk fat concentration $(\mathrm{R}=0.32, P=0.09)$. This suggests that increased availability of BHBA, and its precursors or products, as metabolic fuel may have permitted increased milk fat synthesis.

\section{Plasma Insulin, Glucose, and NEFA}

Plasma insulin responds to energy intake, especially glucose and its precursors, and it both regulates and is regulated by energy utilization in various tissues, including liver, muscle, adipose, and mammary tissue. As cows consumed more BP and less HMC, both plasma insulin concentration and the standard deviation of insulin concentration over $24 \mathrm{~h}$ decreased (Table 9). A linear decrease was detected for both mean $(P<0.001)$ and standard deviation $(P<0.01)$ of plasma insulin as $\mathrm{BP}$ increased. Plasma glucose concentration tended to decrease linearly with added $\mathrm{BP}(P=0.06)$. As might be expected, plasma glucose concentration was positively correlated with plasma insulin concentration among cow-period observations (Table 10). Plasma glucose:insulin increased with added BP $(P<0.05$; Table 9$)$, indicating that the relationship between glucose and insulin concentration was affected by treatment. However a cause-effect relationship cannot be determined.

The tendency for a more negative BCS change with added BP (Table 9 ) might be caused by the corresponding decreases in DMI, plasma glucose, or plasma insulin concentration in response to BP. However, among cow- 
Table 10. Pearson correlation coefficients between plasma insulin concentration and characteristics of intake, production, and energy balance.

\begin{tabular}{|c|c|}
\hline & $\begin{array}{l}\text { Plasma insulin }{ }^{1}, \\
\mu \mathrm{IU} / \mathrm{ml}\end{array}$ \\
\hline Plasma glucose $^{2}, \mathrm{mg} / \mathrm{dl}$ & $0.45^{3}$ \\
\hline $\mathrm{DMI}, \mathrm{kg} / \mathrm{d}$ & $0.41^{3}$ \\
\hline Total tract starch digested, $\mathrm{kg} / \mathrm{d}$ & $0.51^{3}$ \\
\hline Milk $\mathrm{NE}_{\mathrm{L}}, \mathrm{Mcal} / \mathrm{kg}$ & $0.51^{3}$ \\
\hline Milk $\mathrm{NE}_{\mathrm{L}}, \% \mathrm{NE}_{\mathrm{L}}$ intake & -0.27 \\
\hline
\end{tabular}

${ }^{1}$ Calculated using eight samples collected over $3 \mathrm{~d}$, representing 3-h intervals of a 24-h day.

${ }^{2}$ Measured for a composite of eight samples collected over $3 \mathrm{~d}$, representing 3 -h intervals of a 24 -h day.

${ }^{3}$ Correlation is significant $(P<0.05)$.

period observations, DMI, plasma insulin, plasma glucose, and plasma glucose:insulin were not related to change in BCS (data not shown). Insulin secretion affects metabolism of adipose tissue, and plasma concentration of NEFA, a product of adipose catabolism, tended to be negatively related to plasma insulin concentration ( $\mathrm{R}=-0.36, P=0.07)$. However, plasma NEFA concentration was not affected by treatment (Table 9 ) and was not related to change in BCS (data not shown). Thus, the mechanism for the BCS effect of treatment is not clear.

Insulin secretion can be affected by intake, ruminal fermentation products, and absorption of metabolites throughout the gastrointestinal tract. Because both DMI and plasma insulin decreased with added BP, lower feed intake might have resulted in lower insulin, although $\mathrm{NE}_{\mathrm{L}}$ intake was not affected by treatment (Table 9). Insulin concentration and DMI were correlated across treatments as well (Table $10 ; \mathrm{R}=0.41, P$ $=0.03$ ). Starch consumed per meal decreased as BP increased (Table 3), so a smaller amount of starch from HMC was undergoing rapid fermentation during and immediately after each meal, and amount and fluctuation of propionate flux to the liver was likely decreased, possibly reducing variation in plasma glucose concentration. While variation of propionate flux and plasma glucose were not measured, plasma glucose concentration was positively correlated with ruminal propionate concentration $(\mathrm{R}=0.48, P<0.01)$. Lower fluctuation of plasma glucose likely resulted in lower plasma insulin concentration and less fluctuation in insulin concentration (Table 9), with the resulting decrease in energy partitioned to adipose tissue indicated by the tendency for decreased BCS.

Insulin secretion is also stimulated by increased plasma glucose concentration. Although there is little net glucose absorption across the portal-drained viscera in cattle (Reynolds, 1995), plasma glucose concentration may be increased by greater gluconeogenesis and by greater availability of glucose-sparing fuels such as acetate, BHBA, and lactate. It can also be increased by greater glucose absorption and utilization in small intestine cells; most of the glucose absorbed in the ruminant small intestine probably is either utilized within intestinal cells, thus sparing circulating glucose, or is absorbed into blood as lactate, which can be used for gluconeogenesis. Although plasma insulin and glucose concentrations decreased with added BP, the amount of starch digested postruminally $(\mathrm{kg} / \mathrm{d})$ was not different among treatments (Voelker and Allen, 2003a); and among cow-period observations, amount or proportion of starch digested postruminally was not related to insulin concentration, so intestinal glucose or lactate absorption alone probably did not contribute to the insulin effect. Only the amount of starch consumed or digested in the whole tract was related to plasma insulin $(\mathrm{R}=$ $0.51, P<0.01$; and $\mathrm{R}=0.52, P<0.01$, respectively), and adding ruminal digestibility of starch to the model did not improve the prediction of insulin concentration from starch intake. Therefore, although replacing $\mathrm{HMC}$ with $\mathrm{BP}$ shifted starch digestion from the rumen to the intestines, the reduced plasma insulin and glucose concentrations with added BP probably were caused by the reduction in the total amount of starch consumed and digested, regardless of the form in which it was absorbed.

\section{SUMMARY}

Substitution of dried, pelleted beet pulp for highmoisture corn resulted in decreased DMI, and ruminal distention probably limited DMI with added beet pulp. Mean and minimum ruminal $\mathrm{pH}$ did not affect DMI, but, independent of treatment effects, increased variation in $\mathrm{pH}$ might have decreased DMI. Replacing highmoisture corn with beet pulp caused a quadratic response for milk fat yield and the tendency for a quadratic response for FCM yield. Partial substitution of pelleted beet pulp for high-moisture corn decreased intake due to filling effects but also permitted similar or greater FCM yield. Beet pulp tended to increase the efficiency of conversion of feed to milk and can be partially substituted for high-moisture corn depending on their relative costs and value of milk produced.

\section{ACKNOWLEDGMENTS}

The authors wish to thank D. G. Main, R. A. Longuski, Y. Ying, M. Oba, C. S. Mooney, R. A. Kreft, and the staff of the Michigan State University Dairy Cattle Teaching and Research Center for their assistance in this experiment. 


\section{REFERENCES}

Allen, M. S. 1997. Relationship between fermentation acid production in the rumen and the requirement for physically effective fiber. J. Dairy Sci. 80:1447-1462.

Allen, M. S. 2000. Effects of diet on short-term regulation of feed intake by lactating dairy cattle. J. Dairy Sci. 83:1598-1624.

Anil, M. H., and J. M. Forbes. 1980. Feeding in sheep during intraportal infusions of short-chain fatty acids and the effect of liver denervation. J. Physiol. 298:407-414.

Bailoni, L., M. Ramanzin, A. Simonetto, N. Oblakov, S. Schiavon, and G. Bittante. 1998. The effect of in vitro fermentation on specific gravity and sedimentation measurements of forage particles. J. Anim. Sci. 76:3095-3103.

Clark, P. W., and L. E. Armentano. 1997. Influence of particle size on the effectiveness of beet pulp fiber. J. Dairy Sci. 80:898-904.

Dado, R. G., and M. S. Allen. 1993. Continuous computer acquisition of feed and water intake, chewing reticular motility, and ruminal $\mathrm{pH}$ of cattle. J. Dairy Sci. 76:1589-1600.

DeJong, A. 1982. Patterns of plasma concentrations of insulin and glucagons after intravascular and intraruminal administration of volatile fatty acids in the goat. J. Endocrinol. 92:357-370.

Forbes, J. M. 1995. Voluntary Food Intake and Diet Selection in Farm Animals. CAB International, New York, NY.

Forbes, J. M., and F. D. Provenza. 2000. Integration of learning and metabolic signals into a theory of dietary choice and food intake. Pages 3-19 in Ruminant Physiology: Digestion, Metabolism, Growth and Reproduction. P. B. Cronjé, ed. CAB International, New York, NY.

Goering, H. K., and P. J. Van Soest. 1970. Forage Fiber Analysis (Apparatus, Reagents, Procedures, and Some Applications). Agric. Handbook No. 379. ARS- USDA, Washington, DC.

Hach, C. C., B. K. Bowden, A. B. Lopelove, and S. V. Brayton. 1987. More powerful peroxide Kjeldahl digestion method. J. AOAC 70:783-787.

Karkalas, J. 1985. An improved enzymatic method for the determination of native and modified starch. J. Sci. Food Agric. 36:10191027.
Mansfield, H. R., M. D. Stern, and E. E. Otterby. 1994. Effects of beet pulp and animal by-products on milk yield and in vitro fermentation by rumen microorganisms. J. Dairy Sci. 77:205-216.

National Research Council. 1989. Nutrient Requirements of Dairy Cattle. 6th rev. ed. National Academy Press, Washington, DC.

National Research Council. 2001. Nutrient Requirements of Dairy Cattle. 7th rev. ed. National Academy Press, Washington, DC.

O’Mara, F. P., J. J. Murphy, and M. Rath. 1997. The effect of replacing dietary beet pulp with wheat treated with sodium hydroxide, ground wheat, or ground corn in lactating cows. J. Dairy Sci. 80:530-540.

Ramanzin, M., L. Bailoni, and G. Bittante. 1994. Solubility, waterholding capacity, and specific gravity of different concentrates. J. Dairy Sci. 77:774-781.

Reynolds, C. K. 1995. Quantitative aspects of liver metabolism in ruminants. Pages 351-372 in Ruminant Physiology: Digestion, Metabolism, Growth and Reproduction, W. v. Englehardt, S. Leonhard-Marek, G. Breves, D. Geisecke, ed. Ferdinand Enke Verlag, Stuttgart, Germany.

Swain, S. M., and L. E. Armentano. 1994. Quantitative evaluation of fiber from nonforage sources used to replace alfalfa silage. J. Dairy Sci. 77:2318-2331.

Van Soest, P. J., J. B. Robertson, and B. A. Lewis. 1991. Methods for dietary fiber, neutral detergent fiber and nonstarch polysaccharides in relation to animal nutrition. J. Dairy Sci. 74:35833597.

Voelker, J. A., and M. S. Allen. 2003a. Pelleted beet pulp substituted for high-moisture corn: 2. Effects on digestion and rumen digestion kinetics in lactating dairy cows. J. Dairy Sci. 86:3553-3561.

Voelker, J. A., and M. S. Allen. 2003b. Pelleted beet pulp substituted for high-moisture corn: 3 . Effects on ruminal fermentation, $\mathrm{pH}$, and microbial protein efficiency in lactating dairy cows. J. Dairy Sci. 86:3562-3571.

Wildman, E. E., G. M. Jones, P. E. Wagner, R. L. Boman, H. F. Troutt, Jr., and T. N. Lesch. 1982. A dairy cow body condition scoring system and its relationship to selected production characteristics. J. Dairy Sci. 65:495-501. 